\title{
Penerapan Teknik Mind Maps dalam Meningkatkan Keterampilan Menulis Siswa
}

\author{
Yusrumaida ${ }^{*}$ \\ ${ }^{1}$ Jurusan Pendidikan Bahasa dan Sastra Inggris, Universitas Pendidikan Ganesha, Singaraja, Indonesia
}

\section{A R T I C L E I N F O}

Article history:

Received July 16, 2021

Revised July 20, 2021

Accepted September 20, 2021

Available online November 25, 2021

Kata Kunci:

Teknik Mind Maps, Keterampilan Menulis

Keywords:

Mind Map Technique, Writing Skill

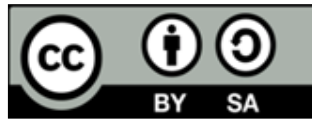

This is an open access article under the CC BY-SA license.

Copyright (ㅇ 2021 by Author. Published by Universitas Pendidikan Ganesha.

\begin{abstract}
A B S T R A K
Menulis menjadi salah satu keterampilan yang harus dimiliki oleh peserta didik selain keterampilan menyimak dan berbicara. Hanya saja kenyataan di lapangan menunjukkan bahwa kemampuan menulis siswa masih tergolong rendah dan berada di bawah nilai rata-rata. Berdasarkan permasalahan tersebut, penelitian ini dilaksanakan dengan tujuan dari untuk meningkatkan keterampilan menulis pada peserta didik kelas VIII SMP melalui teknik mind maps. Penelitian ini adalah penelitian tindakan kelas yang dilaksanakan dalam dua siklus. Setiap siklus terdiri dari rencana tindakan, pelaksanaan tindakan, observasi atau evaluasi, dan refleksi. Subjek yang terlibat dalam penelitian ini yakni siswa kelas VIII SMP. Pengumpulan data dalam penelitian dilakukan dengan menggunakan metode observasi dan tes. Instrumen yang digunakan dalam penelitian ini yakni berupa tes kemampuan dasar menulis serta tes kemampuan menulis dengan teknik mind maps. Analisis data hasil penelitian dilakukan dengan menggunakan teknik analisis statistik deskriptif. Hasil penelitian menunjukkan bahwa rata-rata nilai keterampilan menulis siklus I yaitu sebesar 65 dan rata-rata nilai keterampilan menulis siklus II yaitu sebesar 80. Dari data hasil belajar tersebut dapat dikatakan bahwa hasil belajar keterampilan menulis pada siklus I ke siklus II mengalami peningkatan sebesar 15. Dapat disimpulkan bahwa hasil keterampilan menulis meningkat melalui penggunaan teknik mind maps pada siswa kelas VIII-5 SMP.
\end{abstract}

A BSTRACT

Writing is one of the skills that students must possess after listening and speaking skills. It is just that the reality on the ground shows that students' writing abilities are still relatively low and below the average value. Based on these problems, the purpose of this research is to improve writing skills in class VIII junior high school students through the mind maps technique. This research is classroom action research that is carried out in two cycles: an action plan, action implementation, observation or evaluation, and reflection. The subjects involved in this study were grade VIII junior high school students. Data collection in the study was carried out using observation and test methods. The instrument used in this research is an essential writing ability test and a writing ability test using a mind map technique. Analysis of the research data was carried out using descriptive statistical analysis techniques. The results of data analysis show that the average value of writing skills in the first cycle is 65 , and the average value for writing skills in the second cycle is 80 . From the learning outcomes data, it can be said that the learning outcomes of writing skills in cycle I to cycle II have increased by 15. Based on the results of data analysis and discussion, it can be concluded that writing skills are increased through the use of mind maps techniques in grade VIII-5 junior high school students.

\section{PENDAHULUAN}

Proses pembelajaran pada kurikulum 2013 menuntut peserta didik untuk mampu menyusun berbagai jenis teks lisan dan tulis, sangat pendek dan sederhana, dengan memerhatikan fungsi sosial, struktur teks, dan unsur kebahasaan secara benar dan sesuai konteks (Mukhlifida, 2021; Puspitasari \& Niopani, 2021). Menulis pada dasarnya merupakan salah satu bentuk keterampilan berbahasa yang dapat digunakan untuk berkomunikasi secara tidak langsung, tanpa melalui proses tatap muka dengan lawan bicara (Fitrianita \& Ramadhan, 2018; Musyafa, 2020; Ramaniyar \& Rosanti, 2018; Sholeh et al., 2021). 
Melalui kegiatan menulis, seseorang dapat menuangkan ide dan gagasannya dalam sebuah karya tulis (Hasan, 2021; Henny \& Fatmasari, 2020). Menulis menjadi keterampilan akhir yang harus dikuasai oleh seseorang individu setelah keterampilan menyimak, berbicara, dan membaca (Sholichah, 2020). Kemampuan menulis seseorang tidak dapat diturunkan atau didapatkan melalui proses yang instan, melainkan harus melalui proses latihan yang rutin dan berkesinambungan (Adeninawaty et al., 2018; Nugraha et al., 2019). Seseorang akan dapat dikatakan memiliki keterampilan menulis yang baik apabila telah mampu menggunakan bahasa tulis yang baik dan benar serta menggunakan ejaan yang tepat (Erina et al., 2018). Kegiatan merancang sebuah tulisan membutuhkan proses yang kompleks. Sebelum menulis, seseorang harus membaca dan menyimak berbagai materi yang berkaitan dengan karya yang akan ditulis (Anggraeni, 2019; Sing et al., 2021; Widiyanto \& Ati, 2019). Seseorang yang telah mampu menulis dengan baik akan memiliki keterampilan berbahasa yang baik pula serta melalui peningkatan keterampilan menulis seseorang individu akan dapat berkomunikasi secara lisan ataupun tulisan dengan baik (N. N. K. Dewi et al., 2019; Gustina, 2019).

Hanya saja kondisi di lapangan menunjukkan bahwa kemampuan menulis siswa masih sangat rendah, Siswa menganggap bahwa menulis merupakan salah satu kegiatan yang membosankan dan membuang banyak waktu (Ati et al., 2018; Huliatunisa, 2020). Hal ini sejalan dengan hasil observasi yang telah dilakukan di kelas VIII SMP Negeri 2 Singaraja. Hasil observasi menunjukkan bahwa sebagai besar siswa tidak menyukai kegiatan menulis. Siswa menganggap bahwa menulis merupakan keterampilan yang sulit. Dalam pembelajaran menulis peserta didik masih sulit dalam menemukan dan menuangkan ide. Kesulitan siswa dalam menemukan ide disebabkan karena dalam proses pembelajaran menulis guru hanya menggunakan metode ceramah dan buku teks sebagai media pembelajaran, yang terkesan membosankan. Kurangnya minat siswa dalam menulis kemudian berdampak pada rendahnya hasil belajar siswa. Hal ini dapat dilihat dari data yang diperoleh menunjukan bahwa 28 peserta didik kelas VIII5 mendapat nilai di bawah standar KKM dan 9 peserta didik mendapat nilai sesuai dengan KKM atau lebih tinggi dari standar KKM pada saat dilakukan pre-test. Nilai ulangan harian peserta didik kelas VIIIA juga menunjukkan bahwa sebagian besar peserta didik mendapat nilai di bawah standar KKM yaitu sebanyak 29 dari 37 peserta didik. Jika kondidsi seperti ini dibiarkan secara terus menerus, rendahnya hasil belajar siswa dalam hal menulis akan berdampak pada penurunan hasil belajar siswa pada keterampilan berbahasa lainnya. Untuk mengatasi hal tersebut, guru dituntut untuk mampu menciptakan proses pembelajaran yang bermakna dan menyenangkan bagi siswa.

Salah satu upaya yang dapat dilakukan untuk mengatasi permasalahan tersebut, yakni dengan menerapkan teknik pembelajaran yang sesuai dengan kebutuhan siswa. Salah satu teknik pembelajaran yang dapat digunakan yakni teknik minp maps. Mind maps merupakan salah satu teknik pembelajaran yang digunakan untuk mengorganisasikan ide-ide yang muncul, ide-ide tersebut kemudian disusun menjadi ide yang runtut dan sistematis, sehingga dapat dengan mudah digunakan untuk menyusun suatu karya tulis (Aprinawati, 2018; Purwantiningsih, 2019; Saharah \& Indihadi, 2019). Teknik mind maps akan dapat memfasilitasi siswa untuk menghubungkan antara ide dan konsep, sehingga siswa dapat dengan mudah menggali informasi dan meningkatkan ketrampilan menulis (Harfika et al., 2020). Pada dasanya, mind maps merupakan suatu cara mengembangkan kegiatan berpikir ke segala arah dan menangkap berbagai pikiran dalam berbagai sudut (Paramita \& Hartati, 2018). Mind Maps mengembangkan cara berpikir divergen dan berpikir kreatif. Mind Maps dapat menjadi alat berpikir organisasional yang sangat hebat yang juga merupakan cara termudah untuk menempatkan informasi ke dalam otak dan mengambil informasi itu ketika dibutuhkan (Sarumaha, 2019; Warahmah et al., 2020).

Beberapa penelitian yang telah dilakukan sebelumnya menyatakan bahwa pembelajaran menulis bahasa Inggris dengan strategi mind mapping pada peserta didik secara signifikan mampu meningkatkan prestasi belajar peserta didik (Fanita, 2021). Penelitian lainnya juga mengungkapkan bahwa penggunaan teknik mind mapping berpengaruh pada keterampilan menulis ringkasan siswa, kususnya dalam pembelajaran bahasa Indonesia (Saharah \& Indihadi, 2019). Hal serupa juga disampaikan oleh penelitian lainnya yakni terdapat peningkatan hasil pembelajaran menulis teks eksposisi setelah siswa dibelajarkan dengan menggunakan model mind mapping (peta pikiran) (Sarumaha, 2019). Berdasarkan beberapa penelitian yang telah dilakukan sebelumnya dapat dikatakan bahwa penggunaan mind mapping dalam proses pembelajaran secara signifikan dapat meningkatkan kemampuan menulis siswa. Hanya saja pada penelitian sebelumnya belum terdapat kajian mengenai penggunaan mind maps pada pembelajaran menulis teks bahasa Inggris siswa Sekolah Menengah Pertama, sehingga penelitian ini difokuskan pada kajian tersebut. Tujuannya, untuk meningkatkan keterampilan menulis pada peserta didik kelas VIII SMP Negeri 2 Singaraja melalui teknik mind maps. 


\section{METODE}

Penelitian ini tergolong ke dalam penelitian tindakan kelas. Penelitian tindakan kelas merupakan penelitian yang mampu menawarkan suatu cara dan prosedur baru untuk memeperbaiki dan meningkatkan kualitas proses belajar-mengajar di kelas mengajar di kelas. Penelitian ini dilakukan dalam dua siklus penelitian. Pada setiap siklus terdapat lima tahap pelaksanaan di antaranya adalah refleksi awal, perencanaan tindakan, pelaksanaan tindakan, observasi atau evaluasi, dan refleksi akhir. Subjek yang terlibat dalam penelitian ini yakni siswa kelas VIII-SMP Negeri 2 Singaraja yang berjumlah 37 orang. Pemilihan kelas yang menjadi subjek penelitian didasarkan pada hasil observasi awal yang menunjukkan bahwa kemampuan menulis siswa masih rendah. Hampir keseluruhan siswa menemui masalah dalam menulis teks, misalnya masih kurang dalam mengembangkan ide dan banyak kesalahan ditemukan dalam penggunaan tata bahasa dalam kalimat yang dihasilkan. Pengumpulan data dalam penelitian dilakukan dengan menggunakan metode observasi, dan tes. Instrumen penelitian yang digunakan yakni berupa tes kemampuan dasar menulis serta tes kemampuan menulis dengan teknik mind maps. Analisis data hasil penelitian dilakukan dengan menggunakan teknik analisis statistik deskriptif.

\section{HASIL DAN PEMBAHASAN}

Hasil

Penelitian ini diawali dengan pelaksanaan siklus I yang didasarkan pada permasalahan yang muncul pada saat pelaksanaan observasi dan wawancara. Hasil yang diperoleh pada siklus I menunjukkan bahwa, rata-rata hasil kemampuan menulis siswa yang diperoleh adalah 65, bila dikonversikan kedalam tabel penialaian Acuan Patokan (PAP) berada pada interval 65-79 termasuk kedalam kriteria sedang, selain itu ketuntasan belajar siswa masih belum sesuai dengan yang diharapkan yaitu hanya 49\%, sehingga indikator keberhasilan belum tercapai yakni minimal 75\%. Kurang maksimalnya hasil yang diperoleh pada siklus I disebabkan kerena ada beberapa kendala yang dihadapi pada siklus I, seperti kurangnya pemahaman tentang kalimat yang koheren, seperti "Happy birthday mom, i hope mom always healthy and not yeat boring teach $i$ am, wish you all the best.", kemudian penggunaan huruf besar dan kecil seperti "HAPPY BIRTHDAY SISTER, I wish you have long life AND Always Healthy", ejaan dan juga tanda baca seperti penggunaan tanda titik, koma dan tanda seru, selanjutnya kurangnya persiapan peserta didik dalam mengikuti pelajaran, hal ini terlihat ketika guru mengajukan pertanyaan peserta didik masih ragu dalam mengemukakan pendapat. Permasalahan yang muncul pada siklus I dapat diatasi dengan menjelaskan kepada peserta didik bahwasannya tidak ada pendapat yang salah atau pun benar, hal yang palin penting adalah mereka harus berani dan percaya diri untuk tampil didepan umum. Banyaknya peserta didik yang kurang disiplin pada saat proses pembelajaran dan guru merasa kurang maksimal dalam memberikan penjelasan dikarenakan kondisi kelas yang kurang kondusif hal ini dapat dilihat ketika proses diskusi di dalam kelompok berlangsung, sebagian besar peserta didik berbicara dengan temannya tentang hal-hal yang tidak berhubungan dengan materi pembelajaran, kemudian membuat keributan dan berjalan kesana-kemari dengan tujuan yang tidak jelas. Beberapa siswa yang kurang aktif juga menjadi kendala pada saat proses pembelajaran hal ini tampak dari beberapa siswa tidak ikut serta bersana teman sekelompoknya ketika berdiskusi dan membuat Mind Maps.

Berdasarkan refleksi siklus I, maka diadakan perbaikan pada siklus II sehingga terjadi peningkatan pada hasil belajar siswa. Melalui beberapa kendala yang ditemui pada siklus I, maka dilakukan perbaikan dan penyempurnaan pada pertemuan siklus II dan hasilnya terjadi peningkatan nilai peserta didik dan respon peserta didik terhadap penggunaan taknik Mind Maps dalam meningkatkan kemampuan menulis mereka.bila dilihat dari persentase ketuntasan secara klasikal sudah mencapai 81\% itu artinya ketuntasan belajar telah tercapai, bila kita bandingkan hasil evaluasi pada siklus I dan siklus II terjadi peningkatan yang cukup signifikan. Hal ini disebabkan oleh kemampuan guru yang sudah maksimal dalam penerapan teknik Mind Maps sehingga peserta didik lebih mudah menuangkan ide dan mengembangkan ide tersebut menjadi sebuah tulisan. Secara umum pada siklus II tidak ada lagi kendalakendala yang dihadapi pada siklus I, ini dibuktikan dari hasil kemampuan menulis peserta didik yang sudah mampu mengembangkan ide-ide mereka kedalam kalimat-kalimat yang koheren, ejaan yang benar dan tata bahasa yang tepat. Peserta didik juga telah berperan aktif dalam kegiatan pembelajaran. Sehingga berdasarkan hal tersebut dapat dikatakan bahwa penerapan teknik Mind Maps dapat meningkatkan hasil menulis peserta didik pada kelas VIII5 SMP Negeri 2 Singaraja.

\section{Pembahasan}

Hasil yang diperoleh berdasarkan hasil analisis penelitian menunjukkan bahwa terdapat peningkatan kemampuan menulis siswa disetiap siklusnya. Peningkatan kemampuan menulis siswa pada tiap siklusnya tidak terlepas dari penggunaan teknik mind maps. Teknik mind maps menjadi salah satu 
teknik pembelajaran yang cocok digunakan untuk meningkatkan kemampuan menulis siswa. Pada teknik mind maps, siswa diminta untuk mencatat atau menuliskan ide-ide penting yang akan dituangkan ke dalam bacaan secara sistematis dan terstruktur (Cemara \& Sudana, 2019; Latifah et al., 2020). Teknik mind maps merupakan salah satu teknik pembelajaran yang dilakukan dengan mengajak siswa untuk membuat sebuah peta pikiran melalui pengingat visual dan sensorik dalam suatu pola ide yang saling berkaitan satu sama lain (Sari et al., 2018; Warahmah et al., 2020). Mind mapping dapat disusun seperti peta sebuah jalan yang dapat digunakan untuk belajar, dapat merangsang munculnya ide-ide baru serta dapat memicu ingatan siswa (Aprinawati, 2018; Fanita, 2021).

Ide-ide baru yang dimunculkan melalui peta pikiran atau konsep yang dirancang dapat digunakan oleh siswa untuk menyusun suatu karya tulis, sehingga proses menulis siswa menjadi lebih mudah. Seperti yang telah dijelaskan sebelumnya bahwa menulis merupakan salah satu kegiatan yang kurang diminati oleh siswa karena dianggap sangat membosankan dan siswa sulit untuk mendapatkan sebuah ide (Barus, 2018; Widiyanto \& Ati, 2019). Anggapan ini sejalan dengan karakteristik kegiatan menulis, yaitu menulis menjadi salah satu kegitan yang kompleks dan membutuhkan keterampilan kusus dalam mengerjakannya (Dewi \& Simbolon, 2021). Sebelum melakukan proses menulis, seorang siswa harus membaca dan menyimak berbagai materi yang berkaitan dengan tulisannya, sehingga tulisan tersebut akan dapat memberikan manfaat pada pembaca, dan mudah untuk dipahami (Dewi et al., 2019; Huliatunisa, 2020). Menulis pada dasarnya merupakan salah satu bentuk komunikasi yang dapat dilakukan tanpa harus bertatap muka dengan seseorang (Gustina, 2019; Puspitasari \& Niopani, 2021). Melalui tulisan seseorang akan dapat menuangkan berbagai ide, pikiran, serta perasaannya dalam bentuk Bahasa tulis. Seseorang dianggap mampu menulis dengan baik apabila telah menguasai penggunaan Bahasa yang baik dan benar, menggunakan ejaan dan tanda baca yang tepat, serta isi tulisannya dapat dipahami dan bermanfaat kepada pembaca.

Beberapa penelitian yang telah dilakukan sebelumnya mengungkapkan bahwa pembelajaran menulis bahasa Inggris dengan strategi mind mapping pada peserta didik secara signifikan mampu meningkatkan prestasi belajar peserta didik (Fanita, 2021). Penelitian lainnya juga mengungkapkan bahwa penggunaan teknik mind mapping berpengaruh terhadap keterampilan menulis ringkasan siswa, khususnya dalam pembelajaran bahasa Indonesia (Saharah \& Indihadi, 2019). Hal serupa juga disampaikan oleh penelitian lainnya yakni terdapat peningkatan hasil pembelajaran menulis teks eksposisi setelah siswa dibelajarkan dengan menggunakan model mind mapping (peta pikiran) (Sarumaha, 2019). Berdasarkan hasil analisis penelitian yang didukung oleh hasil penelitian terdahlu dapat diketahui bahwa penggunaan teknik mind maps sangat cocok untuk meningkatkan keterampilan menulis siswa di berbagai jenjang pendidikan.

\section{SIMPULAN}

Penerapan teknik pembelajaran mind maps secara signifikan dapat meningkatkan keterampilan menulis peserta didik kelas. Hal ini ditunjukkan dengan adanya peningkatan kemampuan menulis siswa di setiap siklusnya. Bisa bisa direkomendasikan bahwa teknik pembelajaran mind maps bisa digunakan sebagai salah satu alternatif untuk meningkatkan keterampilan menulis.

\section{DAFTAR RUJUKAN}

Adeninawaty, D., Soe'oed, R., \& Ridhani, A. (2018). Penerapan Model Pembelajaran Discovery Learning Strategi Think Talk Write dalam Meningkatkan Motivasi dan Hasil Belajar Menulis Teks Ulasan Kelas VIII SMP. Diglosia: Jurnal Kajian Bahasa, Sastra, Dan Pengajarannya, 1(2), 75-88. https://doi.org/10.30872/diglosia.v1i2.11.

Anggraeni, P. R. (2019). Implementasi Kebijakan Literasi Sekolah Guna Peningkatan Karakter Gemar Membaca. Indonesian Journal of Sociology, Education, and Development, 1(2), 132-142. https://doi.org/10.52483/ijsed.v1i2.12.

Aprinawati, I. (2018). Penggunaan Model Peta Pikiran (Mind Mapping) untuk Meningkatkan Pemahaman Membaca Wacana Siswa Sekolah Dasar. Jurnal Basicedu, 2(1), 140-147. https://doi.org/10.31004/basicedu.v2i1.35.

Ati, A. P., Widiyarto, S., \& Suyana, N. (2018). Penerapan Metode Picture and Picture untuk Peningkatan Keterampilan Menulis Narasi pada Siswa Kelas VIII SMP Al Ihsan Dan SMP Tashfia Kota Bekasi. Adimas : Jurnal Pengabdian Kepada Masyarakat, 2(1), 30. https://doi.org/10.24269/adi.v2i1.887.

Barus, I. W. (2018). Peningkatan Keterampilan Menulis Cerpen Melalui Penerapan Model Pembelajaran Discovery Learning dengan Bantuan Media Film Pendek pada Siswa Kelas IX.13 SMP Negeri 2 $\begin{array}{lllll}\text { Singaraja. Journal of Education Action Research, } 142 . & \end{array}$ 
https://doi.org/10.23887/jear.v2i2.12322.

Cemara, G. A. G., \& Sudana, D. N. (2019). Pengaruh Model Pembelajaran SAVI Bermuatan Peta Pikiran terhadap Kreativitas dan Penguasaan Kompetensi Pengetahuan IPA Siswa. Jurnal Ilmiah Sekolah Dasar, 3(3), 359. https://doi.org/10.23887/jisd.v3i3.18895.

Dewi, L. L., \& Simbolon, M. E. (2021). Pengaruh Penggunaan Metode Cooperative Script terhadap Keterampilan Menulis Narasi pada Muatan Bahasa Indonesia. Kamboti of Journal Education $\begin{array}{llll}\text { Research } & \text { 2(1), Development, 1-23. }\end{array}$ https://ojs3.unpatti.ac.id/index.php/kamboti/article/view/4464/3359.

Dewi, N. N. K., Kristiantari, M. . R., \& Ganing, N. N. (2019). Pengaruh Model Pembelajaran Picture and Picture Berbantuan Media Visual terhadap Keterampilan Menulis Bahasa Indonesia. Journal of Education Technology, 3(4), 278. https://doi.org/10.23887/jet.v3i4.22364.

Erina, E., Triani, S. N., \& Oktavia, W. (2018). Penerapan Model Think Talk Write untuk Meningkatkan Keterampilan Menulis Parafrasa Puisi pada Siswa SMK Negeri 3 Singkawang Tahun Ajaran 2016/2017. JP-BSI Uurnal Pendidikan Bahasa Dan Sastra Indonesia), 3(1), 6. https://doi.org/10.26737/jp-bsi.v3i1.448.

Fanita, I. (2021). Meningkatkan Kemampuan Menulis Siswa dengan Menggunakan Mind Mapping pada Pembelajaran Bahasa Inggris Kelas XI . IPS . 1 SMAN Sungai Lala. Jurnal Pendidikan Tambusai, 5(3), 5911-5916. https://jptam.org/index.php/jptam/article/view/1889/1669.

Fitrianita, D., \& Ramadhan, S. (2018). Korelasi Keterampilan Memahami Teks Deskripsi dengan Keterampilan Menulis Teks Deskripsi Siswa Kelas Vii SMP Negeri 15 Padang. Jurnal Pendidikan Bahasa Dan Sastra Indonesia, 7(3), 55-61. https://doi.org/10.31227/osf.io/e2gda.

Gustina, G. (2019). Peningkatan Keterampilan Menulis Puisi dengan Menggunakan Model Experiential Learning pada Siswa Kelas III Sekolah Dasar. Jurnal Pendidikan Dan Konseling (JPDK), 1(1), 11-24. https://doi.org/10.31004/jpdk.v1i1.337.

Harfika, H., Thahir, R., \& Hambali, H. (2020). Pengaruh Metode Mind Mapping terhadap Minat Belajar Biologi Konsep Monera Siswa Kelas X SMA. Binomial, 3(1), 61-72. https://doi.org/10.46918/binomial.v3i1.481.

Hasan, H. (2021). Peran Media Gambar Berseri terhadap Kemampuan Menulis Karangan Siswa Sekolah Dasar. Ainara Journal (Jurnal Penelitian Dan PKM Bidang Ilmu Pendidikan), 2(4), 169-175. https://doi.org/10.54371/ainj.v2i4.99.

Henny, A., \& Fatmasari, E. (2020). Peningkatan Keterampilan Menulis Bahasa Inggris dengan Menggunakan Metode Pembelajaran Kooperatif Melalui Permainan Chain Word Flag. Jurnal Studi Guru Dan Pembelajaran, 3(2). https://doi.org/10.30605/jsgp.3.2.2020.312.

Huliatunisa, Y. (2020). Upaya Meningkatkan Kemampuan Menulis Puisi Melalui Penggunaan Teknik Akrostik pada Pembelajaran Tematik. Didaktika Tauhidi: Jurnal Pendidikan Guru Sekolah Dasar, 7(2), 121. https://doi.org/10.30997/dt.v7i2.2847.

Latifah, A. Z., Hidayat, H., Mulyani, H., Siti Fatimah, A., \& Sholihat, A. (2020). Penerapan Metode Mind Mapping untuk Meningkatkan Kreativitas pada Pembelajaran Pendidikan Kewarganegaraan. Jurnal Pendidikan, 21(1), 38-50. https://doi.org/10.33830/jp.v21i1.546.2020.

Mukhlifida, N. (2021). Meningkatkan Hasil Belajar Bahasa Inggris pada Keterampilan Speaking Materi Monolog Descriptive Lisan Sederhana yang Berterima Melalui Model Project Based Learning. Educational: Jurnal Inovasi Pendidikan \& Pengajaran, 1(1), 153-163. https://doi.org/10.51878/educational.v1i1.103.

Musyafa, N. F. (2020). Penggunaan Model Picture and Picture dalam Pembelajaran Menulis Cerpen. Jurnal Bahasa, Sastra, Dan Pengajaran, 9(1), 37. https://doi.org/10.35194/alinea.v9i1.626.

Nugraha, J., MS, Z., \& Fuad, N. (2019). Peningkatan Keterampilan Menulis Deskripsi Melalui Pendekatan Saintifik dengan Metode Problem Based Learning Di Kelas IV Sekolah Dasar. Prosiding Seminar Nasional Pendidikan KALUNI, 2, 118-124. https://doi.org/10.30998/prokaluni.v2i0.37.

Paramita, S., \& Hartati. (2018). Pengembangan Model Mind Mapping Berbantuan Gambar untuk Meningkatkan Hasil Belajar Menulis Paragraf. Joyful Learning Journal, 7(2). https://doi.org/10.15294/jlj.v7i2.24726.

Purwantiningsih, S. (2019). Penggunaan Metode Pembelajaran Mind Mapping untuk Meningkatkan Kemampuan Mengarang Siswa di Sekolah Dasar. Jurnal Pendidikan Dasar Setiabudhi, 3(1), 19-27. https://stkipsetiabudhi.e-journal.id/jpds/article/view/79/53

Puspitasari, P. I., \& Niopani, M. I. (2021). Penggunaan Strategi Please dalam Meningkatkan Keterampilan Menulis. Indonesian Gender and Society Journal, 1(1), 19. https://doi.org/10.23887/igsj.v1i1.38985.

Ramaniyar, E., \& Rosanti, K. (2018). Pengaruh Penerapan Strategi Pembelajaran the Power of Two terhadap Kemampuan Menulis Resensi. Jurnal Pendidikan Bahasa, 7(2), 308. 
https://doi.org/10.31571/bahasa.v7i2.1009.

Saharah, S., \& Indihadi, D. (2019). Penggunaan Teknik Mind Mapping pada Keterampilan Menulis Ringkasan Siswa dalam Pembelajaran Bahasa Indonesia. Jurnal Ilmiah Pendidikan Guru Sekolah Dasar, 6(1), 9-15. http://ejournal.upi.edu/index.php/pedadidaktika/index.

Sari, K. W. M., Margunayasa, I. G., \& Kusmariyatni, N. N. (2018). Pengaruh Model Pembelajaran Kolaboratif Berbantuan Peta Pikiran terhadap Hasil Belajar IPA. International Journal of Elementary Education, 2(3), 246. https://doi.org/10.23887/ijee.v2i3.15964.

Sarumaha, F. (2019). Penerapan Model Mind Mapping (Peta Pikiran) terhadap Keterampilan Menulis Teks Eksposisi Siswa Kelas X IPS SMA Kristen Hosana Medan 2018/2019. Asas: Jurnal Sastra, 8(2). https://doi.org/10.24114/ajs.v8i2.15441.

Sholeh, A., Veryliana, V., \& Darsimah, D. (2021). Meningkatkan Keterampilan Menulis Deskripsi dengan Model Picture and Picture di SDN 3 Bangkleyan Kabupaten Blora. Jurnal Paedagogy, 8(3), 454. https://doi.org/10.33394/jp.v8i3.3910.

Sholichah, D. N. dkk. (2020). Pengembangan Media Popscrap Book untuk Pembelajaran Menulis Teks Eksposisi di Kelas V Sekolah Dasar. Jpgsd, Volume 08(Nomor 04), 714-726. https://ejournal.unesa.ac.id/index.php/jurnal-penelitian-pgsd/article/view/35862.

Sing, Kartini, \& Saputra. (2021). Penerapan Teknik Mind Mapping untuk Meningkatkan Keterampilan Menulis Teks Eksplanation. Indonesian Gender and Society Journal, 2(1), 33. https://doi.org/10.23887/igsj.v2i1.39584.

Warahmah, M., Mawardi, \& Nurasiah. (2020). Pengaruh Metode Pembelajaran Inkuiri dengan Model Mind Mapping (Peta Pikiran) terhadap Prestasi Belajar Siswa Kelas VII SMP Negeri 13 Banda Aceh. Jurnal Ilmiah Mahasiswa Pendidikan Sejarah, 5(1), 67-76. https://doi.org/10.24815/jimps.v5i1.15083.

Widiyanto, S., \& Ati, A. P. (2019). Pengaruh Metode Snow Ball Throwing dan Minat Belajar Terhadap Keterampilan Menulis Kalimat Argumen Siswa SMK Insan Mulia Kota Bekasi. Judika (Jurnal Pendidikan Unsika), 7(November), 36-46. https://journal.unsika.ac.id/index.php/judika/article/view/1803. 